\title{
Denunciafauna - A social media campaign to evaluate wildlife crime and law enforcement in Peru
}

\author{
Noga Shanee ${ }^{1}$ \\ Sam Shanee \\ Reclaim Conservation, UK \\ Neotropical Primate Conservation, UK \\ Asociación Neotropical Primate Conservation Perú, Perú
}

\begin{abstract}
Wildlife crime poses a major threat to wild fauna globally. International treaties and laws seldom provide effective solutions. The campaign 'Denuncia Pública General de Casos de Fauna Silvestre en Cautiverio' (General Public Complaint Against Captive Wildlife), in short Denunciafauna, ran from April 2014 to April 2017 as an experiment to empirically assess the capacity of Peruvian wildlife authorities to address animal trafficking. We used a political ecology activist research framework, where the campaign is part of research examining on-the-ground responses to complaints and opportunities for collaboration with civil society. During the campaign we collected information on 179 cases of wildlife crime involving animals, from which 214 official complaints were made. These cases involved thousands of illegally held and traded individuals. The official complaints included the illegal possession of animals at tourist attractions, in private homes, markets, circuses, street vendors, and as part of initiatives authorized by the State. Forty-four per cent of the complaints did not result in any type of intervention by the wildlife authorities. In a further $26 \%$ of cases we, the complainants, have not been informed of the results of the complaint. Thirty per cent of complaints resulted in the confiscation of all or some of the animals involved, but only $7 \%$ of all reported cases led to an official investigation by the public prosecutor, and of these, only 3\% (7 cases) resulted in a court appearance with a sentence given or pending. We describe 'typical' cases which illustrate some of the quantitative results. These quantitative results, cases presented, and participative observation methodologies were used to examine the main limitations of wildlife authorities in Peru. Chronic deficiencies have consistently resulted in the very limited responses of Peruvian wildlife authorities to attend to official complaints and their inability to provide efficient and proportionate responses to wildlife crime, and, in some cases, to even promote or participate in illicit activities. However, pressure and support from civil society can significantly improve authorities' performances.
\end{abstract}

Keywords: Wildlife trafficking, activism, corruption, environmental crime; impunity

\section{Resumé}

La criminalité liée aux espèces sauvages est une menace majeure pour la faune à travers le monde. Les lois et traités internationaux sont rarement une solution efficace. La campagne 'Denuncia Pública General de Casos de Fauna Silvestre en Cautiverio' (Plainte publique concernant des cas d'espèces sauvages en captivité), ou Denunciafauna, a duré d'avril 2014 à avril 2017. Cette campagne a permis d'évaluer la capacité des autorités

\footnotetext{
${ }^{1}$ Dr. Noga Shanee, Kisugu Rd. Namuwongo, Kampala, Uganda, nogashanee "at" gmail.com, +256 785780941. Dr. Sam Shanee. Email: sam "at" neoprimate.org. Affiliations: Reclaim Conservation, Manchester, UK; Neotropical Primate Conservation, Cornwall, UK and Asociación Neotropical Primate Conservation Perú, Lima, Perú. We would like to thank the referees, and all those people who with their tip-offs tried to give a second chance of life to thousands of captive wild animals. Our special thanks to Izzy Hunt, Manuel Portocarrero Mondragón, Patricia Mendoza, Samantha Lopez, Ana Lucía Vicat, Sandra Almeyda Zambrano, Yeissy Sarmiento Guevara, Vanessa Vela del Aguila, Alvaro Anicama González, Jessica Gálvez Durand, Luis Mendo Alegría, Angela Maldonado, Luis Zari, Nestor Allgas, Maeva Moissonnier, and Erick Roque for all their help and support in the field and in the preparation of this manuscript.
} 
animalières du Pérou à aborder le problème du trafic animalier. Nous avons utilisé une structure de recherche d'écologie politique, où la campagne fait partie d'une recherche examinant, sur le terrain, les réponses aux plaintes, ainsi que les opportunités de collaboration avec la société civile. Durant la campagne, nous avons collecté des informations sur 179 cas de crime liés aux animaux sauvages, à partir desquels 214 plaintes officielles ont été déposées. Ces cas impliquaient des milliers d'individus retenu et échangés illégalement. Les plaintes officielles comprenaient la possession illégale d'animaux sur des lieux d'attraction touristiques, dans des résidences privées, des marchés ou vendeurs de rue, ainsi que dans des cirques, mais aussi dans des cas d'initiatives approuvées par l'État. Quarante-quatre pourcents (44\%) des plaintes n'ont abouti à aucun type d'intervention par les autorités animalières. Dans vingt-six pourcents (26\%) des cas, nous - les plaignants n'avons pas été informés des résultats de la plainte. Trente pourcent (30\%) des plaintes ont menés à la confiscation de tous, ou d'une partie des animaux impliqués, mais seulement sept pourcents (7\%) des cas reportés ont menés à une enquête officielle par le procureur général. Et parmis ceux-la, seulement trois pourcents (3\%) ont menés à une sentence délivrée ou en attente. Nous décrivons aussi des cas «typiques» qui illustrent certains des résultats quantitatifs. Ces résultats quantitatifs, cas présentés, et méthodologies d'observation participative, ont été utilisés afin d'examiner les limitations principales des autorités animalières du Pérou. Des lacunes chroniques ont fréquemment abouti à une capacité limitée de la part des autorités animalières du Pérou à pouvoir suivre les plaintes officielles, ainsi qu'à leur inaptitude à pouvoir réagir de façon efficace et proportionnées aux crimes liés aux animaux sauvages, voire même dans certains cas, aller jusqu'à la promotion ou la participation à des activités illicites. Cependant, le support de la société civile, ou bien sa capacité à faire pression, peut se révéler être d'une importance considérable dans l'amélioration de la performance des autorités.

Mots-clés: Traffic d'animaux sauvages, activisme, corruption, crime environnemental, impunité

\section{Resumen}

Los delitos contra los animales silvestres representan una importante amenaza para la fauna a nivel mundial. Los tratados y leyes internacionales rara vez brindan soluciones efectivas. La compaña 'Denuncia Pública General de Casos de Fauna Silvestre en Cautiverio', en breve Denunciafauna, se llevó a cabo desde abril 2014 hasta abril 2017 como un experimento para evaluar empíricamente la capacidad de las autoridades peruanas a cargo de los temas de fauna silvestre para abordar el tráfico de animales. Utilizamos la ecología política como marco de investigación, donde la campaña es parte de una investigación que examina las repuestas a las quejas y oportunidades de colaboración con la sociedad civil. Durante la campaña, recopilamos información sobre 179 casos de delitos contra la vida silvestre que involucraban animales, por los cuales se presentaron 214 quejas oficiales. Estos casos involucraron a miles de individuos ilegalmente retenidos y comercializados. Las quejas oficiales incluyeron la posesión ilegal de animales en lugares turísticos, viviendas particulares, mercados, circos, puestos de venta ambulantes y como parte de iniciativas autorizadas por el Estado. Cuarenta y cuatro por ciento de las quejas no dieron lugar a ningún tipo de intervención por parte de las autoridades de fauna silvestre. En otro 26\% de los casos, nosotros, los denunciantes, no hemos recibido mayor información del resultado de la queja. El treinta por ciento de las quejas resultaron en la confiscación de todos o algunos de los animales involucrados, pero solo el 7\% de todos los casos denunciados conllevaron a una investigación oficial por parte del fiscal, y de estos, solo el 3\% (7 casos) resultó en comparecencia ante el tribunal con una sentencia dada o pendiente. Describimos casos "típicos" que ilustran algunos de los resultados cuantitativos. Estos resultados cuantitativos, casos presentados y metodologías de observación participativa se utilizaron para examinar las principales limitaciones de las autoridades de fauna silvestre en Perú. Las deficiencias crónicas de las autoridades consistentemente resultaron en respuestas muy limitadas para atender las quejas oficiales y su incapacidad para proporcionar respuestas eficientes y proporcionadas a los delitos contra la vida silvestre y, en algunos casos, incluso para promover o participar en actividades ilícitas. Sin embargo, la presión y el apoyo de la sociedad civil pueden mejorar significativamente el desempeño de las autoridades.

Palabras clave: Tráfico de fauna silvestre, activismo, corrupción, crimen ambiental, impunidad

\section{Introduction}

Internationally, wildlife trafficking ranks among the most lucrative illegal trades, together with illegal drugs, arms, and human trafficking (TRAFFIC 2019). Peru is one of the world's "mega-diverse" countries due to its richness in species of wild fauna and flora (McNeely et al. 1990), however, Peruvian wildlife is severely threatened by unsustainable anthropogenic development activities, as well as habitat destruction, hunting, and 
wildlife trafficking. Levels of wildlife trafficking in Peru are amongst the highest in South America and possibly globally, resulting in the loss of countless animals each year (Daut et al. 2015; Shanee et al. 2017).

Many studies have examined the drivers and effects of wildlife trafficking in the tropics (Clarke and Rolf 2013; Broad et al. 2014; 't Sas-Rolfes et al. 2019), typically focusing either on the animals hunted or the traffickers and criminal networks (Gastañaga et al. 2011; Ayling 2013; Daut et al. 2015; Morgan and Chng 2018). Although several studies have focused on corruption within national authorities (Peh and Drori 2010; Wyatt and Cao 2015; van Uhm and Moreto 2017; Wyatt 2017; Wyatt et al. 2018), fewer have tried to provide a more holistic examination of on-the-ground responses by wildlife authorities (Nijman 2017). There is even less focus on interactions with, and cooperation between, authorities and civil society in tackling wildlife crime (White 2012; Maldonado and Peck 2014; Daut et al. 2015). Of all regions, South America has been the focus of the least research and public attention on wildlife trafficking (Reuter and O'Regan 2017).

This investigation was designed as a political ecologist activist study, where the authors engaged with the subject both on academic and practitioner levels (Rocheleau 2008; Demmer and Hummel 2017). The Denunciafauna campaign (General Public Complaint Against Captive Wildlife or Denuncia Pública General de Casos de Fauna Silvestre en Cautiverio in Spanish) was launched in April 2014 by N. Shanee as part of her work for Anglo-Peruvian charity Neotropical Primate Conservation (NPC). It was a social media-based campaign designed as an experiment to allow empirical analysis of the responses and capacities of Peruvian wildlife authorities to effectively control wildlife crime. Publicity in social media and posters in public areas invited people to confidentially submit information about wildlife that was illegally held in captivity or trafficked. The information submitted was handed to the environmental public prosecutor's office, national or regional wildlife authorities and/or Police by members of NPC without compromising the identity of the person or persons providing the information. All data received through the campaign, as well as follow up actions resulting from official complaints, were recorded together with information about resulting actions (inspections and confiscations) that we directly participated in.

The main aims of the campaign were to:

1. Confiscate animals and ensure traffickers receive proper penalties.

2. Identify the abilities and deficiencies of wildlife authorities in acting against wildlife crime.

3. Draw the authorities' and public's attention to wildlife crime in Peru and the problems of its control.

Largely due to its rich biodiversity, Peru is a hotspot for wildlife trafficking (Daut et al. 2015; Shanee et al. 2017). The openness with which wildlife is illegally traded and used suggests a general complacency and lack of enforcement on the part of authorities. This article aims to analyze the results of this campaign within the framework of political ecology. It assesses the Peruvian authorities' response to wildlife trafficking, including institutional, legal, and technical aspects, as well as their interaction with the public. We also assess the influence of civil society intervention on the authorities' efficiency.

\section{Methods}

The study took place between April 2014 and April 2017 during the authors' time as co-directors of the yellow-tailed woolly monkey project, run by NPC. We used a range of interdisciplinary methods under a political ecology activist research framework. Political ecology offers a wide range of methodologies taken from different disciplines and is therefore flexible enough to capture and portray the complexity of a multifaceted situation such as the authorities' response to wildlife trafficking in Peru. It tracks interactions at different levels including the household, local decision makers and interest groups, as well as economic aspects and legal and social processes (Blaikie and Brookfield 1987; Bryant and Bailey 1997). This wide range of aspects is examined to produce 'a chain of explanation' linked to the sources and magnitudes of environmental problems and solutions offered (Stonich 1993; Blaikie 1995).

Nature 2.0 is a term used by political ecologists researching new trends in the online interactions between internet users, nature, conservation agents and other stakeholders (Büscher et al. 2017). Information is not only 
consumed, but also modified and co-produced by the audience, with different levels of engagement, and it effects on-the-ground conservation policy, actions and perceptions (Büscher 2017; Checker 2017; Fletcher 2017; Hawkins and Silver 2017; Lunstrum 2017; Nelson 2017). At the center of the study was the Denunciafauna campaign, set up as a catalyst to induce increased interaction both with the public (submitting information) and the authorities (attending to official complaints). Information about the campaign was published on social media networks, mainly Facebook, with photos of captive wildlife and short messages against wildlife trafficking, encouraging people to send information. An email address was set up to receive anonymous information (denunciafauna@gmail.com). Posters containing the same information were also displayed at key sites (bus stations, universities, markets and around previously identified wildlife trafficking hotspots). These social media posts and posters asked people to submit information about cases identified, including the; number of animals, species (Common name), date of sighting, address or location where the animals could be found, type of location (e.g. private home, tourist center, market, etc.), condition i.e. alive/dead (bushmeat, skin, taxidermized, etc.), state of health of the animal (if live), condition of captivity (caged, chained, free, etc.), and photos if possible. Whenever possible, information reported was verified through a site visit, internet search, and/or cross-referenced through multiple informants. We also asked that informants indicate why they chose to inform us rather than report directly to the authorities. The campaign's aims were published online, so that informants were aware that the confidential information they provided would be used for law enforcement, research and awareness raising purposes. Furthermore, the majority of informants provided us the information with the specific intent that it be used for official complaints, in the hope of seizing the animal and/or punishing the offender.

Official complaints were made to the most appropriate authorities (Table 1) depending on the type of complaint, region, and species involved. Complaints included information on legally threatened and CITES listed species, which are considered aggravated offenses in Peru and therefore carry tougher penalties. We tried to reach a variety of authorities in each region. In some cases, the complaints were delivered through formal channels and in others through informal telephone calls or personal visits to the corresponding authority's office. Due to accessibility issues, most complaints made to the Environmental Public Prosecutors (FEMA - Fiscalia Especializada en Materia Ambiental) were made at the FEMA office in Bongará, Amazonas and subsequently internally referred to the FEMA of the corresponding region. When authorities did not respond promptly to complaints, we resubmitted them to the same and/or other authorities. The results of the different complaints were followed up through formal letters, telephone calls, emails or visits to the respective offices.

In each case we recorded whether or not it was a formal complaint, the authority where the complaint was filed, submission date, any actions taken and their corresponding date, whether NPC participated in any resulting action, and the number of animals and species of animals confiscated. In the case of complaints to the FEMA's office, we added the case number and any legal actions taken, as well as the reasons given when no action was taken.

Interactions with authorities, offenders and informants were recorded and analyzed using ethnographic methods, including informal interviews and field notes. Unplanned, informal interviews, in the form of spontaneous conversations, were used because of their non-standardized character, especially beneficial with complicated or sensitive subjects (Fielding and Thomas 2001). Participatory observation methods were used during the submission of complaints. Whenever possible we accompanied authorities during confiscations, in which we helped with animal handling and transportation to adequate centers, provided carrying cages and other equipment, gave official declarations as witnesses, assisted in species identification, and any other technical assistance requested of us. In most cases recording was not possible during the intervention or communications and so we wrote field notes as soon as possible after the operation. We also reviewed national and international laws relevant to wildlife law enforcement. The combination of different methods enhanced the quantity and diversity of data collected through its validation.

Preliminary results were disseminated through reports, talks and training workshops given to authorities and popular media. The ethical guidelines of the Association of Social Anthropologists of the United Kingdom and Commonwealth (ASA 1999) were adhered to throughout the study. The identities of all participants in this study are disguised, unless explicit consent was given. 


\begin{tabular}{|c|c|c|}
\hline Authority & Function & Scope \\
\hline $\begin{array}{c}\text { National Forestry and Wildlife } \\
\text { Service (SERFOR) }\end{array}$ & $\begin{array}{c}\text { The technical-regulatory authority SERFOR is } \\
\text { responsible for policies and promulgating laws and } \\
\text { procedures related to forestry and wildlife management. } \\
\text { SERFOR is the CITES authority in Peru. }\end{array}$ & National \\
\hline $\begin{array}{c}\text { Environmental Public } \\
\text { Prosecutor (FEMA) }\end{array}$ & $\begin{array}{c}\text { Oversees and carries out investigation and prosecution } \\
\text { of environmental crimes in the public interest and } \\
\text { enforces court orders. }\end{array}$ & National \\
$\begin{array}{c}\text { Forest Resources and Wildlife } \\
\text { (OSINFOR) }\end{array}$ & $\begin{array}{c}\text { Responsible for monitoring and overseeing the } \\
\text { resources, and environmental services permits granted } \\
\text { by the State. }\end{array}$ & National \\
\hline $\begin{array}{c}\text { National Customs and Tax } \\
\text { Administration (SUNAT) }\end{array}$ & $\begin{array}{c}\text { Oversees and controls trade and brings action against } \\
\text { contraband goods, customs duty and tax fraud. }\end{array}$ & National \\
\hline $\begin{array}{c}\text { Technical Administration of } \\
\text { Wild Flora and Fauna (ATFFS) }\end{array}$ & $\begin{array}{c}\text { Local forestry and wildlife authorities as part of the } \\
\text { decentralization of powers. Dependent on SERFOR, } \\
\text { there are still 13 ATFFS that need to transfer functions } \\
\text { to regional governments. }\end{array}$ & Regional \\
\hline $\begin{array}{c}\text { Regional Environmental } \\
\text { Authorities }\end{array}$ & $\begin{array}{c}\text { Regional forestry and wildlife authorities. Created } \\
\text { through the process of decentralization, putting natural } \\
\text { resource management under regional government } \\
\text { control. }\end{array}$ & Regional \\
\hline
\end{tabular}

Table 1: The principal wildlife authorities in Peru.

\section{Results}

We received information about 179 cases of wildlife kept in captivity or being traded, leading to a total of 214 complaints being submitted to the various wildlife authorities. Of these, 113 (53\%) were submitted to the Environmental Public Prosecutors (FEMA), 54 (25.2\%) to the National Forestry and Wildlife Service (SERFOR), 12 (5.6\%) to the respective regional Technical Forestry and Wildlife Administrations (ATFFS), 30 (14.0\%) to the respective Regional Governments / Regional Environmental Authorities (RG/ARA), and 3 (1.4\%) to other institutions. These were the Agency for Supervision of Forest Resources and Wildlife (OSINFOR), Customs authority, and the police (Table 1).

A hundred and thirty-seven (64\%) of the complaints were submitted through formal channels to FEMA or through the official SERFOR portal, and 77 (36\%) were made informally, by telephone or in person, directly to the different authorities. The majority of complaints (75\%) included at least one individual of a species categorized as threatened under Peruvian Law (DS004-2014-MINAGRI) or listed under CITES appendix I.

Complaints received and submitted included cases of wildlife kept by private individuals, wildlife traffickers, and animals used at tourist attractions. Eleven of the cases reported concerned commerce or possession of bushmeat, skins or stuffed animals. We also received information about projects authorized by the government, but which did not comply with legislation, and also acts of corruption by public officials, illegal zoos, authorized zoos that kept animals in poor conditions, and circuses (Table 2).

We received information from 23 of Peru's 24 regions (Figure 1). The main reasons given by informants for using the Denunciafauna email address instead of reporting directly to authorities were a lack of clear information on where and how to file complaints, previous negative experiences with environmental authorities (including rejection of, or reluctance to attend to complaints, and rumors of corruption), distrust in the ethics of the authorities, fear that they would be exposed as informants, and uncertainty as to what authorities would do with any animals seized. 


\begin{tabular}{|c|c|c|c|c|c|c|c|}
\hline & 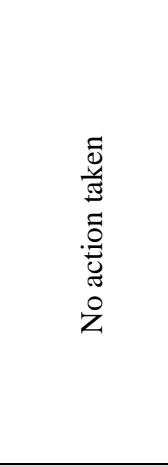 & 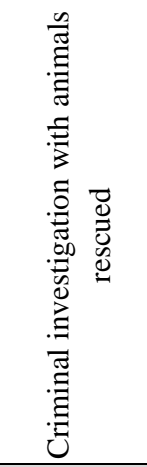 & 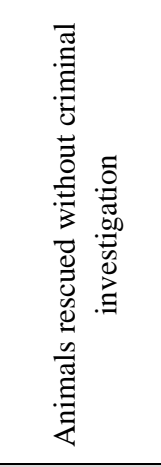 & 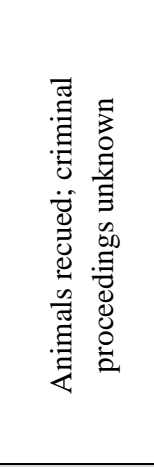 & 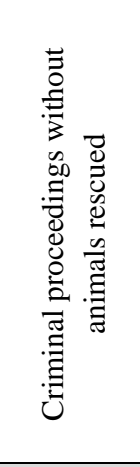 & 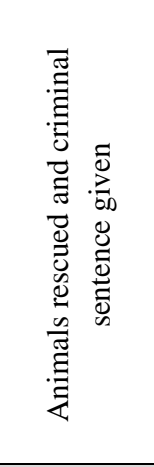 & 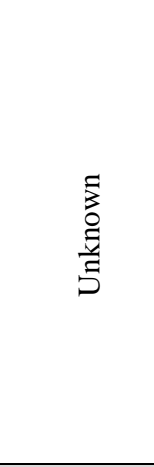 \\
\hline \multicolumn{8}{|c|}{ Institution } \\
\hline FEMA & $40.0 \%(46)$ & $6.1 \%(7)$ & $16.5 \%(19)$ & $7.0 \%(8)$ & $0.9 \%(1)$ & $2.6 \%(3)$ & $25.2 \%(29)$ \\
\hline SERFOR & $55.6 \%(30)$ & - & $3.7 \%(2)$ & $9.3 \%(5)$ & - & - & $31.5 \%(17)$ \\
\hline ATFFS & $83.3 \%(10)$ & - & - & - & - & - & $16.7 \%(2)$ \\
\hline Regional Government & $26.7 \%(8)$ & $3.3 \%(1)$ & $26.7 \%(8)$ & $16.7 \%(5)$ & - & $6.6 \%(2)$ & $20.0 \%(6)$ \\
\hline OSINFOR & $100 \%(1)$ & - & - & - & - & - & - \\
\hline SERNANP & - & - & - & - & - & - & $100 \%(1)$ \\
\hline PNP & - & - & $100 \%(1)$ & - & - & - & - \\
\hline Overall & $44.4 \%(95)$ & $\begin{array}{c}3.7 \% \\
(8) \\
\end{array}$ & $14.0 \%(30)$ & $8.4 \%(18)$ & $0.5 \%(1)$ & $3.2 \%(7)$ & $25.7 \%(55)$ \\
\hline \multicolumn{8}{|c|}{ Case type } \\
\hline Tourist attraction & $34.5 \%(19)$ & $1.8 \%(1)$ & $14.5 \%(8)$ & $10.9 \%(6)$ & - & $1.8 \%(1)$ & $36.4 \%(20)$ \\
\hline Market/trafficker & $40.0 \%(20)$ & $14.0 \%(7)$ & $16.0 \%(8)$ & $4.0 \%(2)$ & - & $2 \%(1)$ & $24.0 \%(12)$ \\
\hline Private owner & $43.8 \%(28)$ & - & $15.6 \%(10)$ & $6.3 \%(4)$ & $1.6 \%(1)$ & $3.2 \%(2)$ & $29.7 \%(19)$ \\
\hline Authorized project & $66.7 \%(8)$ & - & $8.3 \%(1)$ & $8.3 \%(1)$ & - & - & $16.7 \%(2)$ \\
\hline Illegal zoo & $90.9 \%(10)$ & - & - & - & - & - & $9.1 \%(1)$ \\
\hline Corruption & $66.7 \%(2)$ & - & - & - & - & $33.3 \%(1)$ & - \\
\hline Other & $62.5 \%(5)$ & - & $25 \%(2)$ & - & - & $12.5 \%(1)$ & - \\
\hline Overall & $44.4 \%(95)$ & $3.7 \%(8)$ & $14.0 \%(30)$ & $8.4 \%(18)$ & $0.5 \%(1)$ & $3.2 \%(7)$ & $25.7 \%(55)$ \\
\hline \multicolumn{8}{|c|}{ Complaint type } \\
\hline Formal & $48.2 \%(66)$ & $\begin{array}{c}2.2 \% \\
(3)\end{array}$ & $10.9 \%(15)$ & $\begin{array}{c}4.4 \% \\
(6)\end{array}$ & $\begin{array}{c}0.7 \% \\
(1)\end{array}$ & $\begin{array}{c}1.4 \% \\
(2)\end{array}$ & $\begin{array}{c}32.1 \% \\
(44)\end{array}$ \\
\hline Informal & $\begin{array}{c}37.7 \% \\
(29)\end{array}$ & $\begin{array}{c}6.5 \% \\
(5)\end{array}$ & $\begin{array}{c}19.5 \% \\
(15)\end{array}$ & $\begin{array}{c}15.6 \% \\
(12)\end{array}$ & - & $\begin{array}{l}6.5 \% \\
\text { (5) }\end{array}$ & $\begin{array}{c}14.3 \% \\
(11)\end{array}$ \\
\hline
\end{tabular}

Table 2: Overview of the outcomes of official complaints according to which institution they were submitted to, the case type (type of trafficking/illegal captivity) of each case, and whether complaints were made through formal or informal channels. 


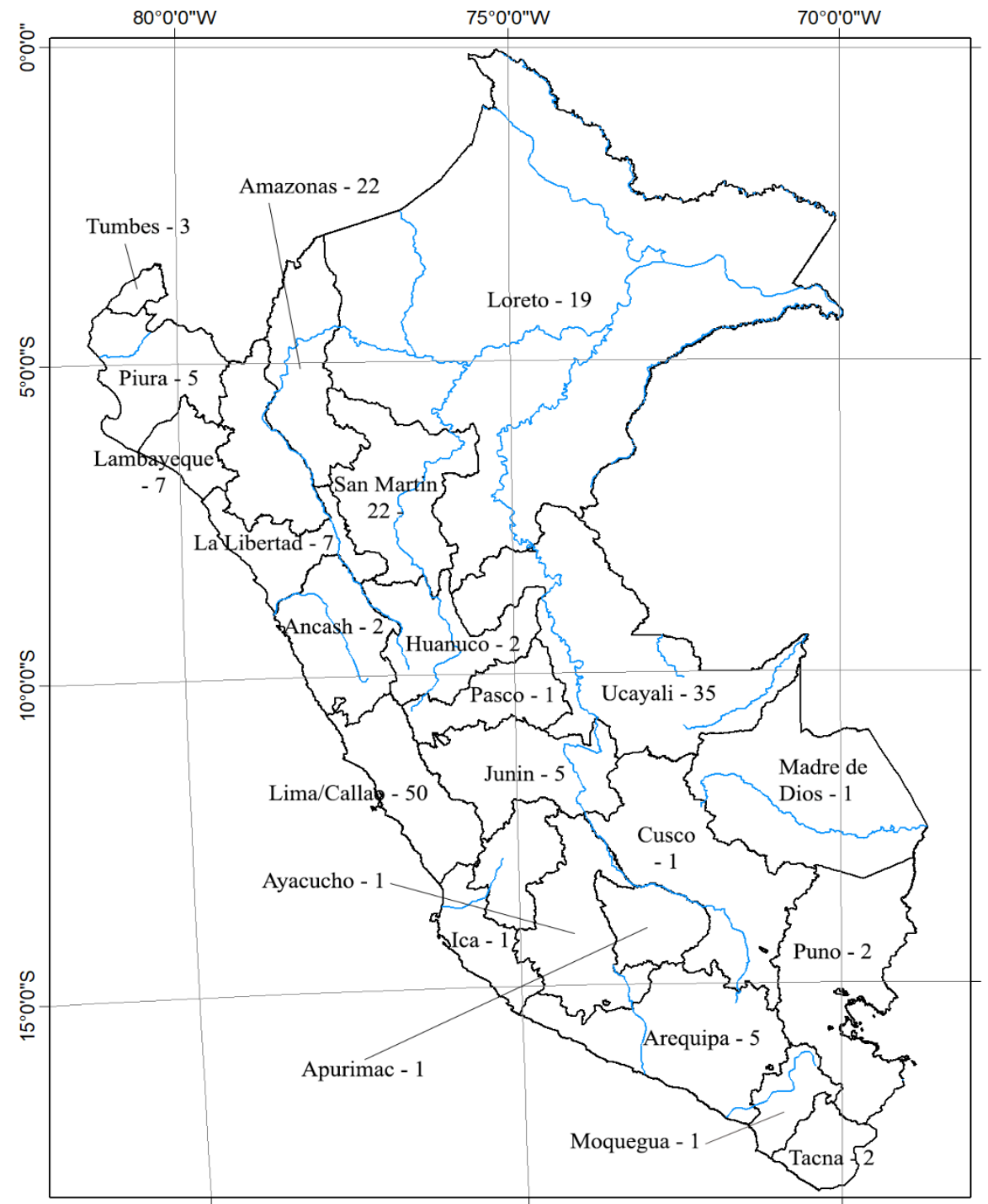

Figure 1: Number of complaints filed per region.

The reasons for mistrust between the public and the authorities are illustrated through the following examples. We reported to the FEMA of Junín region about a group of Dinomys branickii (large rodent indigenous to South America) kept as attractions at a roadside tourist center. When authorities arrived to confiscate the animals, they were aggressively resisted by the owner and many dozens of local residents. In the end only a few of the animals were confiscated. During this operation the authorities gave the animals' owner a copy of the complaint we had filed, which included the first author's personal contact details, resulting in dozens of threatening phone calls during subsequent weeks. Similarly, the owners of an illegal zoo located in a private house in Tacna were also given our contact details by the investigating authorities, and subsequently started a media campaign against the NGO we represent (Neotropical Primate Conservation) and threatened legal action. We also received proof of an instance where local wildlife authorities contacted a complainant in a case involving an illegal zoo and demanded that the complainant withdraw their complaint, threatening to euthanize all animals as they claimed not to have funds to transfer them to other facilities. 


\section{Wildlife seizures}

Formal complaints were processed slowly; $44.7 \%$ took longer than two months from initial complaint to final outcome (including those archived without any action taken), and we have still not heard about the result of another $40.2 \%$ of formal complaints. Some cases have taken over two years and are still not concluded. Informal complaints were generally attended to sooner, with some actions taken within 24 hours (Table 3), especially in cases where NPC was directly involved in organizing and/or took part in the operation. Of the 47 complaints in which representatives of NPC took part in the intervention, 83\% resulted in the successful seizure of the animals. As these complaints were not formally registered however, many were ignored or did not result in any action (Table 2).

\begin{tabular}{|c|c|c|}
\hline \multirow{2}{*}{ Time taken } & \multicolumn{2}{|c|}{ Formal } \\
\cline { 2 - 3 } & Yes & No \\
\hline 24 hours & $6.1 \%$ & $23.1 \%$ \\
\hline 1 week & $3.8 \%$ & $20.0 \%$ \\
\hline 1 month & $5.3 \%$ & $7.7 \%$ \\
\hline 2 - 4 months & $16.7 \%$ & $6.2 \%$ \\
\hline 4 months - 1 year & $2 \%$ & $2 \%$ \\
\hline > 1 year & $3 \%$ & $3.1 \%$ \\
\hline No intervention & $23.5 \%$ & $21.5 \%$ \\
\hline Unknown & $40.2 \%$ & $16.9 \%$ \\
\hline
\end{tabular}

Table 3: Time elapsed between submission of complaint and action taken, comparing formal and informal complaints.

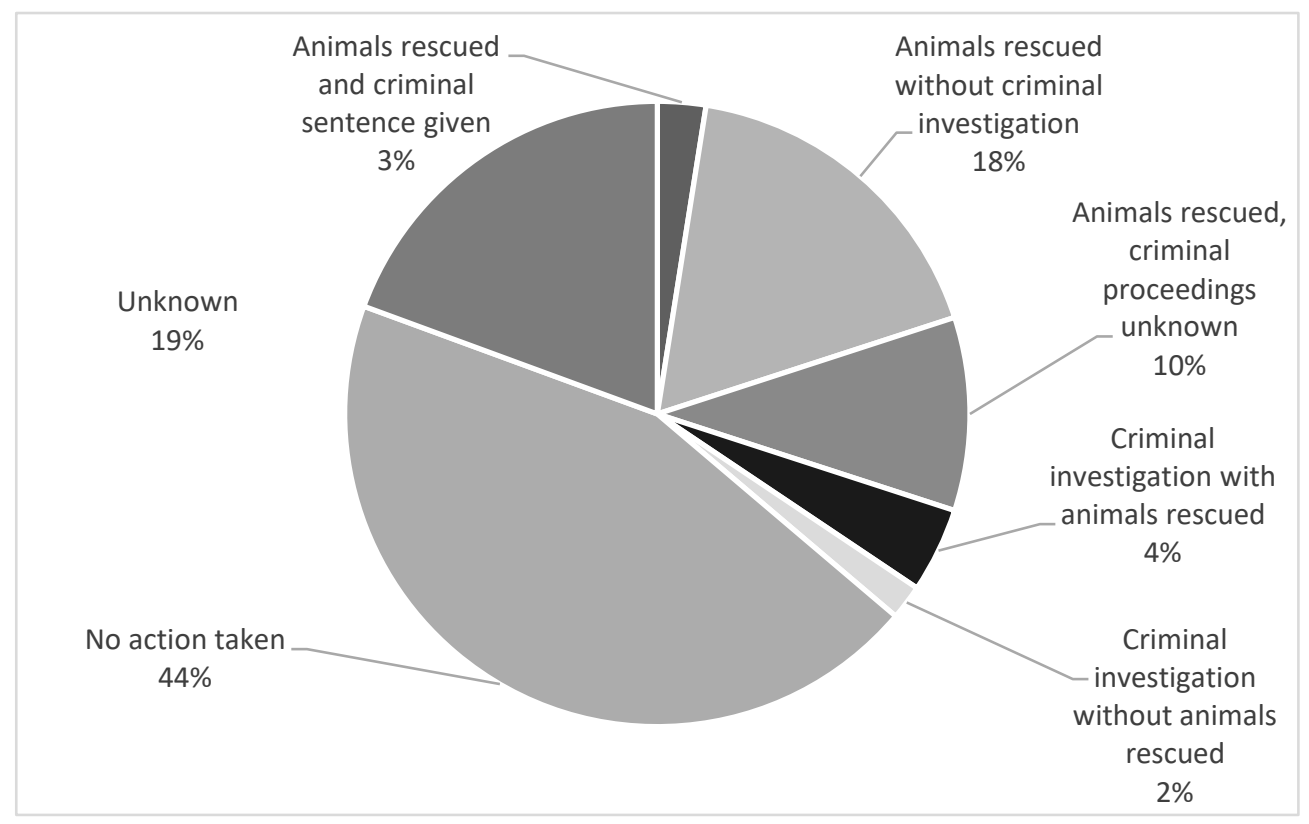

Figure 2: Final results of complaints which included at least one individual of a species categorised as threatened (DS 004-2014- MINAGRI and/or CITES I). 
As well as formal complaints being processed slowly, not all were even attended to. To date, authorities have not, after repeated requests, provided us with information about the results of $25.7 \%$ of complaints. In $44.4 \%$ of cases no action was taken, often without explanation. In some cases, the length of time it took for authorities to act meant that no animals were found. In other cases when the complaint was not addressed, we were referred to another authority. In $14.0 \%$ of cases animals were rescued but the offenders were not subject to criminal investigation. In $7.4 \%$ of cases a criminal investigation was begun, but only 3.2\% (7 cases) were taken to court (4 resulting in sentencing, and 3 still pending) (Table 2). This trend was also seen for aggravated cases alone, $n=160$ (Figure 2). Two cases reported to the authorities in 2015 are still in trial, awaiting sentencing. To date, 879 animals are confirmed to have been seized as a result of complaints we made during this campaign.

The impact that the actions, or lack thereof, of authorities, can have on wildlife trafficking are significant. This is well illustrated through the case of the "Bellavista" market, in Pucallpa, Ucayali region. The market, managed by the local municipality, was the largest open wildlife market in Peru and one of the largest in Latin America (Mendoza and Cavero 2014; Shanee 2015). Amongst the general market stalls, a variety of illegal goods were sold, including wildlife and wildlife products. Periodic surveys at the market between 2007 and 2012 registered up to 1,104 wild animals from 76 different species, openly displayed for sale (Mendoza and Cavero 2014). Beginning in April 2014, a series of successful interventions led by the FEMA of Ucayali, using information provided by our informants, resulted in a substantial reduction in wildlife in the market, sometimes down to less than a dozen parakeets recorded. However, no vendor was ever arrested. Subsequent changes in personnel in local authorities resulted in a reduction in the number of interventions, and animal trade increased again.

A report on the need to close the market was presented to the Regional Government, FEMA and the Criminal Prosecutors Office, together with a media campaign against the market (Shanee 2015). In October 2015, the market was demolished and relocated to a new site. Demolition of the market was a big step, leaving traffickers without direct access to the public. But traffickers have relocated their storage and sales points to different locations around the city, including in the new municipal market and around the old market site. Our observations suggest that wildlife is again increasingly being openly offered for sale.

Another clear example of inaction, or reticence to act, on the part the authorities involves the company 'On Vacation'. On Vacation has two nearby hotels along the Peru-Colombia border in the Amazon, one in each country. The Colombian hotel has more than one hundred animals, including many protected species, and the hotel staff have admitted on record that animals were illegally brought from Peru. The company also arranges trips to a Peruvian village, Vista Alegre, to take pictures ("selfies") with wild-caught animals. This information was reported to both FEMA and SERFOR, with photographic and audio evidence, in February 2015. We are also aware of other complaints that were made by others to FEMA on the same issue. To date, we have not received any details of action taken. When we followed up on the case, FEMA stated that no such file existed and that they are not aware of the issue or any of the place names mentioned.

\section{Legal proceedings and fines}

Under Peruvian law, environmental offenders can face two parallel processes; either an administrative process managed by the ATFFS or Regional Environmental Authorities, which is an automatic fining system set under the Forestry and Wildlife Law, or alternatively, juridical prosecution by FEMA, which, according to the Penal Code, can result in effective or suspended incarceration. According to the same code, the default is that a sentence of $<4$ years be suspended. As mentioned above, only seven complaints ended in a court process or sentencing. In one case a professional trafficker was filmed during a sting operation with dozens of wild animals at her home and offering them for sale. Recordings included the suspect receiving payment of marked bank notes for 20 animals. She received a suspended sentence of two years and six months and was fined $\mathrm{S} / 2,362.50$ ( US\$550). Another case involved a trafficker who was caught in flagrante delicto, meaning he was supposed to be sent for immediate trail, but the case was only presented to the court months later. We presented documents and recordings proving his role as a major wildlife trafficker, that he knowingly committed these crimes and that he was bribing government officials. Furthermore, he was found in possession of animals of 
three threatened species under D.S 004-2014-MINAGRI and listed on CITES. The prosecutor only asked for a three year suspended sentence, the minimum allowed and his case is still in court awaiting sentencing. In further cases another private owner received a 3 year 8 month suspended sentence for keeping an endemic Andean night monkey (Aotus miconax) and a parrot as pets, and another private owner who kept a young spectacled bear (Tremarctos ornatus), which died through negligence of the owner during a seizure operation, received a 3 year 5 month suspended sentence.

Cases involving corrupt officials, rarely reach court, and even then, punishments are light. For example, a regional environmental official from Amazonas was reported for various irregularities and brought to trial for authorizing a private individual to keep endangered wildlife. He was acquitted, although the crime took place in 2014, the sentence was passed in 2016, by which time newly enacted regulations had downgraded the severity of the offense. The judge ruled that the official had committed an offense and should be fined, but this never happened due to the time that had elapsed between the offense and the trail. The implicated official returned to work, occupying the same post.

Despite being criminal offenses, most cases we reported were not investigated by the prosecutor or were archived before reaching court. Many reasons were given for the archiving of cases (Table 4), which were often arbitrary. For example; in May 2014, we reported 3 Humboldt's penguins (Spheniscus humboldti), considered Endangered under Peruvian law, being kept in very poor conditions at a restaurant in Arequipa. After a visit, the ATFFS confirmed the need to confiscate the animals, but left them in the temporary custody of the restaurant. Soon after, one of the penguins died. Even though Peruvian law does not allow private individuals custody of protected species, the public prosecutor archived the case, stating that the temporary custody was authorized. At no point was the legality of acquiring the animals, their living conditions or ATFFS' decision mentioned in the prosecutor's decision.

\begin{tabular}{|c|c|c|c|c|c|c|c|c|c|}
\hline \multicolumn{2}{|c|}{$\begin{array}{l}\text { Reason given for } \\
\text { archiving case }\end{array}$} & 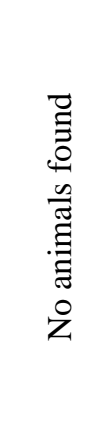 & 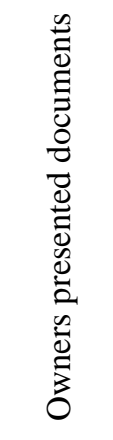 & 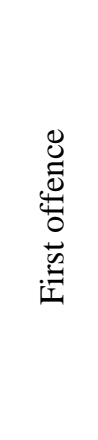 & 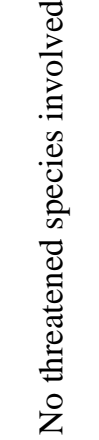 & 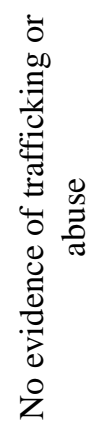 & 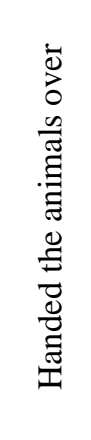 & 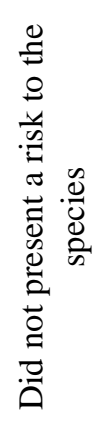 & 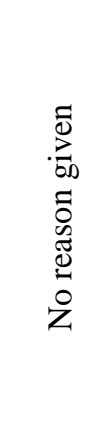 \\
\hline \multirow{2}{*}{$\begin{array}{l}\text { Threatened } \\
\text { species } \\
\text { involved }\end{array}$} & Yes & $\begin{array}{c}24.3 \% \\
(25)\end{array}$ & $\begin{array}{c}16.5 \% \\
(17)\end{array}$ & $\begin{array}{c}5.8 \% \\
(6)\end{array}$ & $\begin{array}{c}1.0 \% \\
(1)\end{array}$ & $\begin{array}{c}7.8 \% \\
(8)\end{array}$ & $\begin{array}{c}1.9 \% \\
(2)\end{array}$ & $\begin{array}{l}3.9 \% \\
(4)\end{array}$ & $\begin{array}{c}38.8 \% \\
(40)\end{array}$ \\
\hline & No & $\begin{array}{l}21.1 \% \\
(8)\end{array}$ & $\begin{array}{l}5.3 \% \\
(2)\end{array}$ & $\begin{array}{l}2.6 \% \\
(1)\end{array}$ & $\begin{array}{l}5.3 \% \\
(2)\end{array}$ & $\begin{array}{l}5.3 \% \\
(2)\end{array}$ & - & - & $\begin{array}{c}60.5 \% \\
(23) \\
\end{array}$ \\
\hline \multicolumn{2}{|c|}{ Total } & $\begin{array}{c}23.4 \% \\
(33)\end{array}$ & $\begin{array}{c}13.5 \% \\
(19)\end{array}$ & $\begin{array}{l}5.0 \% \\
(7)\end{array}$ & $\begin{array}{l}2.1 \% \\
(3)\end{array}$ & $\begin{array}{l}7.1 \% \\
(10)\end{array}$ & $\begin{array}{c}1.4 \% \\
(2)\end{array}$ & $\begin{array}{l}2.8 \% \\
(4)\end{array}$ & $\begin{array}{c}44.7 \% \\
(63)\end{array}$ \\
\hline
\end{tabular}

Table 4: Reasons given for the archiving of cases which did/did not include threatened species. Only cases where we were informed of the definitive archiving of the case are included.

Peruvian law considers all unauthorized extraction and possession of wildlife illegal, without regard to the numbers of individuals involved (Forestry and Wildlife law 29763). In one particular case however, a prosecutor from San Martin archived a complaint about three yellow spotted river turtles (Podocnemis unifilis) stating that, although the specimens were kept in inadequate conditions and without authorization, the actions 
did not put the species at risk. They concluded that the extraction of small quantities of a threatened species is insignificant for their conservation, and closed the case.

Prosecutors often explain the archiving of cases due to the existence of a previous administrative process, such as a fine given by wildlife authorities, stating that a second case cannot be opened for the same crime. However, according to our observations and interviews with professional informants, this is legally possible and has occurred in many other cases.

The clearest example of an arbitrary file closure is FEMA Case No. 3006015202-2014-84-0 from Ucayali, where in a one-and-a-half-page long document the environmental prosecutor describes and archives five different complaints. These involved; a private owner with 1 woolly monkey, a threatened species with no documentation, an owner with 20 macaws and parrots, 1 toucan and 1 young anteater, the majority of which are considered threatened and had no documentation, an owner with 1 macaw with a broken wing, again a threatened species with no documentation, multiple animals in the Bellavista market, including many threatened species without documentation, and "Zoo La Jungla", which held hundreds of animals, many of which were threatened species kept in extremely poor conditions, and did not have full approval yet. In the first 3 cases the animals were confiscated, some were also confiscated from the Bellavista market, however, none were confiscated from the "Zoo La Jungla".

The reason for closure of all of these files was given as:

... There is no element of conviction that can sustain an illicit crime has been committed. Because the people had acted out of ignorance about owning wildlife, and because we have achieved the confiscation of the animals mentioned by the Executive Directorate of Forestry of Ucayali, this case will be archived. Taking into account that the labor of prevention by this office has been fulfilled .... (Author translation)

\section{User service and communication of results}

In $25.7 \%$ of cases we still have not received a response from authorities regarding the results of the complaint, despite numerous formal and informal requests being made. We received no answer to $31.5 \%$ of the complaints given to SERFOR, either through its portal (alerta@serfor.gob.pe) or in person. SERFOR forwarded us letters passing the complaints to the respective regional authorities, but no response has since been given by the regional authorities to SERFOR detailing actions taken. According to an interview with a key SERFOR informant, this is due to the chronic lack of communication with regional authorities, especially the Regional Environmental Authorities, because of the great autonomy they have.

\section{Limitations of wildlife authorities}

In all of our interactions with wildlife authorities, during the Denunciafauna campaign and in the more than a decade of work in Peru, we have been able to identify some of the major limitations of wildlife authorities, that significantly decrease their efficiency in enforcing wildlife laws. Some of these limitations have been briefly mentioned in our earlier publications (Shanee 2012, 2016; Shanee et al. 2017). Below we cover these in more detail based on the findings of the Denunciafauna campaign.

\section{Contradictory, complicated legislation and lack of trained personnel}

In September 2015, Peru's current Forestry and Wildlife Law came into force. Since then, most of the legal guidelines about wildlife have not been approved for publication, leaving many loopholes open to interpretation and thus weakening legislation.

In general, application of much of the wildlife law depends on the capacity of personnel to perform many specialized tasks for which they are seldom properly trained. Myriad species need to be properly identified, including differentiating them between native fauna, alien fauna and domestic species, which species are categorized as threatened, and what constitutes an infraction or an aggravated offence, including CITES listed species and whether aggravated offenses include species categorized in Appendix II or just Appendix I. Clear 
definition of the terms "legally protected species" and "threatened species" is lacking. The main effect of this is that people, including authorities, often believe that if a species is not included on the official list of threatened species, published under D.S. 004-2014-MINAGRI, then it is not protected by law, which is untrue. Of those present during a seminar given by NPC to wildlife authorities in Loreto (Peru's largest Amazonian region), none of the wildlife authorities' personnel or environmental police officers stated that they had read the forest and wildlife regulations.

The drafting of the new Wildlife and Forestry Law was made through a participatory process, which allowed different stakeholders to influence the law. In many cases, those who work with wildlife introduced easements to the law. For example, the new law allows the transfer of wildlife from one facility to another with paperwork only needing to be signed by representatives of the facilities, and no need for the signature of one of the authorities. This severely limits the opportunities to control captive breeding centers that move animals between sites with no prior notice, opening new opportunities for the 'laundering' of fauna.

Whilst most of the fauna regulations remain unpublished, some Legislative Decrees, such as $\mathrm{N}^{\circ} 1283$ and $\mathrm{N}^{\circ} 1319$ published in 2016, simplify processes and therefore permit numerous types of wildlife exploitation, in some cases contravening their parent legislation. For example, the decrees stated above relax the procedures for the sale of certain specimens from zoos, not requiring them to be accredited breeding facilities: this contravenes the forestry law. These contradictory decrees were annulled after a short period. But even so, they helped to generate confusion and open opportunities that directly benefits wildlife criminals. They also give a strong indication that authorities in Peru, even at the highest level, are influenced by external interest groups, such as zoo owners who wished to increase revenue in a way that was previously prohibited.

The excess of bureaucracy and institutional inertia set by the law, are generally used by authorities to account for their low efficiency in combating wildlife crime. Paperwork occupies a lot of time for authorities and increases with every operation. The responsibility for acting against wildlife crime is split between multiple institutions, causing confusion and inefficiencies, hindering their effectiveness. The need to coordinate operations between different institutions means that preparations for an operation can take several months, by which time it is often too late.

One of the most serious problems identified whilst accompanying authorities was that, given the severe punishments stipulated by the new Forestry and Wildlife Law, many authorities choose not to press charges at all, especially when dealing with pet animals. The principal reason is the severity of the punishments; the minimum fine, $S / .40,000$ ( US\$13,000 at the time the current law came into effect), would significantly affect the life of most rural Peruvians. To avoid pressing charges, many authorities list the animal as 'found' rather than confiscated. This not only leaves offenders unpunished but also un-recorded, meaning that repeat offenders are not identified, and national statistics of wildlife crime are severely underestimated.

Specialized wildlife personnel are very few in number. The same officers are often in charge of all environmental issues, including illegal logging, illegal mining and pollution, and most of the officers have a forestry background, causing wildlife crime to be treated as a low priority. There is also a rapid turnover of personnel, meaning that experienced staff are regularly replaced leaving untrained personnel responsible for the enforcement of wildlife crime laws. For these and other reasons, we have found that authorities are more willing to act, and are more efficient when they do, when accompanied by a wildlife specialist.

The lack of capacity among authorities is particularly problematic as successful prosecutions rely on these officers providing detailed technical reports for use in court. If the official is not experienced in wildlife matters, the report will be sub-standard and seldom lead to a successful prosecution. An example of a seemingly small error making a significant difference was a report where black-faced spider monkeys (Ateles chamek) were identified as "capuchin monkey (Ateles poniscus)". Ateles chamek is categorized as Endangered by the D.S. 004-2014-MINAGRI, but the incorrectly spelt Ateles poniscus is not in the Threatened Species list, and capuchin monkeys are not categorized as threatened, therefore this case of an aggravated offense was not treated as such by the prosecutors. Such errors are common.

The lack of proper training also means that authorities often have difficulty understanding what wildlife trafficking is and what the consequences are. During interventions, it is common to hear officers talking about their favorite bushmeat dish or considering out loud the possibility of taking one of the seized animals home as 
a pet. These comments, when heard by offenders, undermine the authority, commitment and professionalism of the officers and greatly reduce the impact of the operation. These types of attitudes are found at all levels; judges state in court that "it is only a monkey" and give offenders minimal or no punishment, prosecutors seemingly arbitrarily archive cases stating that "there is no evidence of trade or abuse" (Table 4), despite confiscating dozens of animals kept in very bad conditions from a single owner or location.

\section{Lack of resources and equipment}

Each of Peru's decentralized regional governments has autonomy to decide the resources it allocates to its environmental authorities, and internally these authorities decide what to allocate to wildlife law enforcement. There is therefore great disparity in resources available between regions. A common trend stated by officials across all environmental institutions in all regions however is a lack of funding and equipment. In Amazonas, for example, a number of personnel resigned after not receiving salaries for several months. Funding for wildlife law enforcement operations are almost nil since the decentralization of environmental responsibilities, and it is common for officials to buy food for rescued animals from their personal finances. Transport is also a problem, since officials often have to use their own vehicles for operations. There is also a general lack of vital equipment, such as transport cages, handling equipment and wildlife identification guides across all regions.

\section{Lack of rescue centers}

One of the most serious deficiencies in Peru is the lack of viable rescue centers for confiscated wildlife. The few centers that do exist receive no support from the Peruvian Government and face heavy bureaucratic requirements to operate legally. All rescue centers are private and, due to fines imposed by OSINFOR for administrative matters, the owners of several centers have decided to leave Peru or have chosen not to receive more animals.

There are also no legal guidelines for the release or reintroduction of wildlife in Peru, despite the need for guidelines being discussed in government workshops for many years. This lack of guidelines means that each organization undertakes releases however they see fit, without following an approved protocol and often without government approval. In addition, of those seeking approval from SERFOR for releases, very few have been approved even when releases are proposed to be performed in line with IUCN or other recognized protocols. This contributes to many rescue centers being full and therefore unable to receive more animals.

This lack of options for placing rescued animals is a major contributing factor in the lack of confiscations in many regions, with authorities reluctant to euthanize animals on perceived animal welfare and/or rights grounds, and it is sometimes used as a pretext for inaction. In some cases, however, the authorities just do not know about the rescue centers that do exist or do not take the initiative to find them.

\section{Lack of investigative action}

There is an obvious and severe lack of intelligence work on the part of Peruvian wildlife authorities. They rarely actively seek out traffickers, use informants, recordings or interrogation. On many occasions the authorities choose to believe the claims of the person arrested, even when evidence clearly shows the explanations given are not true. Similarly, authorities rarely check if defendants have previous convictions or complaints against them for environmental violations.

Intelligence work depends largely on the police; however, many prosecutors have little confidence in the police because of rampant corruption. Prosecutors often only inform the police minutes before an operation to avoid leaks, however this means that there is little or no prior investigation.

\section{Corruption and impunity}

This investigation highlighted two main forms of corruption within the Peruvian authorities: low-level, "classic" or "everyday" corruption (Blundo et al. 2013; Sundström 2015), including, among other things, the receipt of bribes, the sale of rescued animals and the illegal delivery of animals to private owners/buyers. And, 
high-level or political corruption (Whitehead 2000; Burnett 2013), much of which stems from cases of classic corruption and takes the form of; intentional chronic underfunding of forestry and wildlife offices, maintaining untrained personnel, dismissal of efficient personnel, the impunity of officials, and the granting of authorizations without adequate supervision. Our observations suggest this type of corruption is covered by the pretense of inefficiencies but is, in some cases intentional policy to weaken the forestry sector or to help cover classic corruption. Peru suffers one of the worst levels of political corruption in Latin America, worsened by processes of neoliberalism and decentralization (Alvarez 2017; Heuser 2018; Dammert and Sarmiento 2019), and manifesting in a wide variety of environmental issues (Arellano-Yanguas 2011; EIA 2012; EIA 2015; Shanee et al. 2017).

In recorded interviews that we conducted together with a TV crew, a wildlife dealer in Loreto explained how he had been paying environmental authorities to turn a blind eye to his activities, and in another interview in the same region a government official openly stated that these kinds of payoffs are the result of poor state salaries (Collyns 2016). Similarly, in another recorded interview, a provincial prosecutor in Iquitos confirmed cases of corruption in the forestry sector in Loreto (West 2017). Corruption occurs at all levels in the forestry sector and is openly recognized and accepted.

A typical example of a case we encountered during the campaign was of an official visit to an unauthorized roadside tourist attraction in Ucayali, in which case the authorities were reluctant to take action against the establishment, stating that the owners had begun the process of being officially licensed as a zoo and captive breeding center. The conditions at the location were very bad, with dirty and broken cages, no enrichment, inadequate food, stressed animals, animals disappearing and new ones arriving without informing the authorities, and a restaurant attached that served bushmeat. The authorities present signed an agreement with the owners requiring welfare improvements and that the owners legalize their operation. Although no improvements were made, our repeated complaints of ongoing issues were all archived. The establishment became legalized as a rescue center in 2016, but informants continue to pass us information on the poor conditions at the center. According to one informant from within the authorities, the owner of the center was related to a former police chief in the region and therefore no action was possible. In another case we were alerted to a plan by the Technical Administration of Flora and Fauna (ATFFS) of Cajamarca Region to declare an amnesty and register the ownership of any wild animals kept as pets throughout the region. This initiative contradicts Peruvian law and national policy. We reported this initiative to SERFOR and started a directed social media campaign. SERFOR immediately stated that it was an initiative of ATFFS of Cajamarca without previous coordination with SERFOR. The initiative was annulled a day later before it even started.

In another similar case a wildlife official of the Ucayali Regional Government had been illegally granting permits for the keeping of wildlife. When questioned, the regional government justified their action by citing a law that was no longer valid. In one specific case we handed a formal complaint to the Governor of Ucayali region and FEMA, as well as an informal notice to SERFOR, about a clearly mistreated young capuchin monkey. We never received a response from the Governor, FEMA archived the case without an investigation, and SERFOR responded by informing the relevant office that the registering of wild animals as pets is illegal. However, no further actions have been taken.

A further example involves a recorded interview with a trafficker from Belen market in Iquitos. The trafficker mentioned repeated dealings with a Colombian national who travels to Iquitos in a private plane accompanied by a Peruvian policeman. Once the animals have been paid for, the dealer, buyer and policeman go together to the regional authorities and pay S/.50.00 ( U \$15.00) per animal for birth registration documents, certifying that the animals were obtained legally from an authorized source. Among the animals sold are many threatened species and others for which there are no authorized breeding centers in Peru.

\section{Discussion}

Anthropologists and political ecologists are calling on academic researchers to critically engage with the subjects of their study, making their research a part of the ethical solution to the socio-environmental problems they explore (Bourgois 2006; Speed 2006; Rocheleau 2008; Bebbington 2012). The Denunciafauna campaign is a result of seven years of prior engagement with Peruvian environmental authorities whilst tackling wildlife 
crime. It was designed to gather empirical information to allow us to assess and improve our own work as well as to facilitate increased efficiency of wildlife law enforcement. At the same time, the campaign resulted in onthe-ground achievements, such as raising public awareness of wildlife traffic issues, the confiscation of wildlife, and the prosecution of illegal wildlife trade and corruption cases.

No estimates of the actual numbers of animals trafficked in Peru are available, although conservative estimates of traffic in vertebrates are in the thousands per day (Ortiz 2010; Gastañaga et al. 2011; Quevans et al. 2013; Figueroa 2014; Daut et al. 2015; Leberatto 2016; Shanee et al. 2017; van Vliet et al. 2018). Our campaign highlighted many obvious deficiencies in the Peruvian environmental sector in controlling wildlife trafficking, as well as several less intuitive issues. Amongst the major problems are: contradictory, complicated and inadequate legislation and lack of trained personnel that leads to the fundamental misinterpretation of relevant laws; chronic under-funding, leaving authorities with a lack of basic resources, equipment and even rescue centers in which to home rescued animals. There is also a passive attitude towards wildlife trafficking and cases of low and high-level corruption, resulting in very little investigative work and even fewer prosecutions, arbitrary closure of cases and the inappropriate issuing of authorizations. These problems lead to the lack of an appropriate response to wildlife trafficking in Peru (ICCWC 2014; Shanee et al. 2017), which is reflected in the minimal presence of authorities in the field, the lack of attention to cases and the scarce work in prevention of crimes against wildlife. Authorities are not properly trained in wildlife issues, and their efficiency is further restricted by a lack of resources and incentives.

Shanee et al. (2017) suggest that authorities in Peru prefer to confiscate from private pet owners and are reluctant to intervene in professional trafficking. This suggestion was confirmed in this study through participant observation and interviews. Some of the reasons given for this reluctance are practical; intervening with traffickers usually means large numbers of animals to handle and rehome. NPC's participation in operations and assistance in rehoming seized animals was frequently requested, to overcome these technical issues. We repeatedly collaborated in organizing and assisting operations in wildlife markets, roadblocks and illegal zoos. The authorities' hesitation increased, however, and often resulted in refusal to intervene at all, when animals were held by economically or politically powerful people. Some openly explained that intervening in such cases would mean immediate removal from their job, whilst others, when asked, provided other explanations, did not respond, or repeatedly lost the relevant files.

Informal complaints where we personally informed the authorities resulted in more immediate action, and in general more rescues. This was due to our physical presence and persistence, as well as our long-term collaboration and the mutual trust established with some individual officers that we identified for their commitment (Shanee 2016). A small minority of officers were willing to receive complaints and act on them outside of office hours and over weekends, even though they did not receive overtime pay. This made a huge difference as most traffickers trusted the authorities' limitations and preferred to operate outside conventional working hours. This study confirms that dedicated individuals inside the system can make a positive difference, but suffer intense institutional and political pressures, which often leads to the termination of their employment (Shanee 2016). The systematic removal of these individuals is one of the symptoms of high-level corruption.

Only $2 \%$ of all cases submitted through the Denunciafauna campaign, and $4 \%$ of the cases which included at least one individual of a species categorized as threatened, ended with criminal charges and sentencing. Because of the decentralized and divided nature of the wildlife authorities in Peru, it was impossible for us, and even for SERFOR, to obtain accurate information on levels of wildlife confiscated nationally, offenders issued with fines, or cases submitted to judicial process during the years of research. As such, comparison of our results with official data was impossible. This highlights one of the most serious problems that decentralization of environmental powers has had on Peruvian authorities, where the national regulatory body is unable to even receive information from the regions on their activities. Earlier investigations and observations, however, suggest that the percentage of successful persecution are even lower nationally. Studies from other countries also suggest similar or even lower percentages of sentencing success and relatively minor sanctions (Broussard 2017; Nijman 2017). To date, no one in Peru has received effective jail time for wildlife trafficking. 
Broussard (2017) classified South East Asian countries according to the organization of their wildlife authorities. The first type gives the leading roles to wildlife agencies, specialized in designing wildlife policies, research and overseeing trade. These agencies are authorized to arrest, confiscate and investigate wildlife crime, but usually prefer administrative sanctions such as fines and the revoking of wildlife management permits. The other type is led by special police units which are better trained, equipped and authorized to run complex criminal investigations and punish serious crime. Their expertise in criminal investigation makes them better able to tackle transnational organized crime. Some countries create hybrid multi-agency task forces (Broussard 2017). Peruvian wildlife authorities don't fully fall in either of these categories. They form part of the general wildlife agencies inside the Ministry of Agriculture and Irrigation. In some regions there are officers that specialize in wildlife law enforcement, but normally the same people are responsible for various different environmental issues. Authorities are supposed to collaborate with the police on interventions but are usually reluctant to do so because the police are notorious for leaking information to traffickers, severely limiting the authorities' investigative options. San Martin region was an example of what can be achieved when there is more political will; From 2011-2017 they had a small specialized and autonomous wildlife and orchid unit and worked in close collaboration with a very dedicated head of the ecological police. Their work was exceptional in Peru until the wildlife unit was dismantled after a change in the regional government (Shanee 2012, 2016; Shanee et al. 2017).

Leberatto (2016) found wildlife trade in Peru mostly opportunistic and unorganized. Although we agree that there is a lot of small scale, opportunistic and local wildlife trade, this study and our previous work (Shanee 2012; Shanee et al. 2017) suggest there is also large scale, well organized, national and international trafficking of wildlife and its derivatives. There is also evidence that the internet is becoming a powerful tool that facilitates the sale of wildlife in Peru. This is a global issue that international wildlife authorities are still not equipped to properly tackle (Lavorgna 2014), and the poor investigative capacity of the Peruvian authorities makes it especially challenging. Another way that traffickers use technology is the recent availability of telephone reception in the jungle. Traffickers no longer need to keep many animals in storage, but can communicate directly with hunters whenever they receive an order (Collyns 2016). This helps traffickers to avoid getting caught with a large number of animals, making it even harder to prove the scale of their operations without proper investigation.

The complexity and contradictions of the legal framework related to wildlife crime in Peru, as exemplified by excessively high minimum fines and a lack of guidelines, facilitates and encourages corruption. The combination of low- and high-level corruption we found during this study means that most offenders do not serve their sentence, strongly reducing the impact of penalties (Sundström 2015) and the effectiveness of wildlife rescues and confiscations (Nijman 2017). The legal wildlife trade has direct and indirect implications for the illegal trade, as corruption undermines the implementation of national and international wildlife laws at all levels of the trade chain (Broussard 2017). Focusing law enforcement efforts on local hunters and other small-scale illicit activities is a justice concern, especially with the high legal consequences meant to stop professional traffickers. These small-scale activities are often conducted out of economic necessity and there are few or no alternatives, but really their perpetrators are exploited by organized environmental criminals and punished by authorities further up the 'chain of explanation' (Wall and McClanahan 2015).

Globally, wildlife trafficking receives much less attention and political will than other illicit markets (Welch 2017). Bennett (2011) warns that chronically weak governance, low capacity and lack of resources of national and international enforcement systems globally, make them inherently inadequate for dealing with such serious crimes, and that in order to save charismatic species they must go through a complete transformation of their perception. It is clear that although there are positive advances, Peruvian authorities are generally passive in their attitude to wildlife crime, not appreciating the scale and significance of the issue, and are unable and ill-equipped to keep up with rapidly changing wildlife traffic trends.

Nature 2.0 literature critically examines conservation NGO's efforts to attract the public to engage with them through interactive online activities, where consumers become co-producers of nature and conservation narratives (Büscher and Igoe 2013). These activities range from playing an educational game, directing funds to one project or another by clicking on options, publicly "shaming" environmentally destructive individuals or institutions, or collaborative organization of direct actions (Lovink 2011; Büscher 2017; Checker 2017; 
McCubbin 2020). Public knowledge can be harnessed as a source of biological and geographical information, feeding conservation actions with reduced economic investment and field effort for conservation groups (Goodchild 2007; Newell et al. 2012). These activities have different levels of direct or indirect effects on offline conservation, determined by the level of activism set by the lead organization. In the Denunciafauna case, online informants saw the direct effect of their actions in the form of animals confiscated and took part in publicly criticizing the authorities regarding cases to which they did not react effectively, leading to missed intervention opportunities.

Non-governmental organizations have the technical skill and resources to facilitate a better response to wildlife trafficking than many governments (Bennett 2011). From our experiences in Peru, however, NGOs did not tend to get involved in law enforcement or wildlife trade investigations. The few NGOs that did involve themselves in wildlife issues were mainly focused on capacity building, lobbying or rehoming rescued animals. Very little to no on-the-ground activism exists. Corruption and inefficiency in wildlife authorities in high biodiversity countries is by now common knowledge, however academic studies of civil activism interventions and their effect on authorities' decision making and actions are still rare.

\section{Recommendations}

Based on our experience, we recommend that a general change of political attitude must take place in Peru, which should lead to the dismantling of existing, poorly-functioning authorities and the establishment of wildlife authorities that are properly trained, equipped and funded to tackle organized crime. Training of environmental authorities should be particularly focused on investigative and intelligence work or through joint taskforces with specialist agencies. Contradictory legislation must be cleared up and legal loopholes closed; laws must be updated and the official threatened species list should be properly maintained well within any stated maximum durations. Corruption also must be urgently addressed at all levels; all instances must be made public, with the officials involved punished according to the law.

Regional governments must be made to comply with national environmental policies, establishing minimum budgets for decentralized environmental authorities, promoting targets for minimum numbers of operations, and demanding free exchange of information between central and regional authorities to ensure that obligations are fulfilled. The current division of responsibilities between different environmental offices limits their effectiveness, therefore wildlife functions should be separated from the forestry sector and moved under the control of the Ministry of the Environment. Currently, to avoid imposing large fines on poor people, many authorities omit details in their reports. We recommend that a system is needed where, if it is proven that there is no commercialization or abuse, and offenders have no prior history of wildlife crime, the law should allow reduced fines and the registration of the offender in a national database, thus enabling the identification of repeat offenders.

Communication and trust between the authorities and the public must be restored; authorities should disseminate contact details where the public can inform instances of environmental crime, ensuring the anonymity of the informer, but also the traceability of actions taken. NGOs and the public should be actively involved in wildlife trafficking control, both by technically assisting the authorities' work and by demanding efficiency and accountability. Furthermore, political ecologists should examine different types of collaboration academically, to find the most effective approaches to bring about the best results in different situations and countries.

\section{Conclusions}

The aim of this article was to analyze the current Peruvian state response to wildlife trafficking and related crimes through the use of an online campaign, used as a catalyst to increase the number of interactions between state authorities, the public, and civil society, and to facilitate the recording of clear data on the processes followed and ultimate actions taken. The results show that, although wildlife authorities suffer chronic deficiencies which severely limit their ability to act effectively, good collaboration with dedicated activist NGOs and the public can increase their capacity. We challenge conservation NGOs to actively engage in tackling wildlife trafficking and other environmental crimes. 


\section{References}

't Sas-Rolfes, M., D.W. Challender, A. Hinsley, D. Veríssimo and E. Milner-Gulland. 2019. Illegal wildlife trade: patterns, processes, and governance. Annual Review of Environment and Resources 44: 201-228.

Alvarez, J.P. 2017. Putting out the fire of anti-corruption demands: the symbolic adoption of a national anticorruption office in Peru, 2007-2008. European Quarterly of Political Attitudes and Mentalities 6(3): $15-31$.

Arellano-Yanguas, J. 2011. Aggravating the resource curse: decentralisation, mining and conflict in Peru. The Journal of Development Studies 47(4): 617-638.

Ayling, J. 2013. What sustains wildlife crime? Rhino horn trading and the resilience of criminal networks. Journal of International Wildlife Law \& Policy 16(1): 57-80.

Bebbington, A.J. 2012. Underground political ecologies: the second annual lecture of the Cultural and Political Ecology Specialty Group of the Association of American Geographers. Geoforum 43(6): 1152-1162.

Bennett, E.L. 2011. Another inconvenient truth: the failure of enforcement systems to save charismatic species. In Wuerthner, G., E. Crist and T. Butler (eds.). Protectecting the wild. Washington: Island Press.

Blaikie, P.M. 1995. Understanding environmental issues. In Morse S. and M. Stocking (eds.) People and environment. London: UCL Press.

Blaikie, P.M. and H.C. Brookfield. 1987. Land degradation and society. London: Methuen.

Blundo, G., J.P. Olivier de-Sardan, N.B. Arifari and M.T. Alou. 2013. Everyday corruption and the state: citizens and public officials in Africa. London: Zed.

Bourgois, P. 2006. Engaged observer: anthropology, advocacy, and activism. New Jersey: Rutgers University Press.

Broad, S., T. Mulliken and D. Roe. 2014. The nature and extent of legal and illegal trade in wildlife. In Oldfield, S. (ed.). The trade in wildlife. London: Routledge.

Broussard, G. 2017. Building an effective criminal justice response to wildlife trafficking: experiences from the ASEAN region. Review of European, Comparative \& International Environmental Law. 26(2): 118127.

Bryant, R.L. and S. Bailey. 1997. Third world political ecology. London: Routledge.

Burnett, M.E. 2013. Letting the big fish swim: failures to prosecute high-level corruption in Uganda. New York: Human Rights Watch.

Büscher, B. 2017. Conservation and development 2.0: intensifications and disjunctures in the politics of online 'do-good' platforms. Geoforum 79: 163-173.

Büscher, B. and J. Igoe. 2013. 'Prosuming' conservation? Web 2.0, nature and the intensification of valueproducing labour in late capitalism. Journal of Consumer Culture 13(3): 283-305.

Büscher, B., S. Koot and I.L. Nelson. 2017. Introduction. Nature 2.0: new media, online activism and the cyberpolitics of environmental conservation. Geoforum 100(79): 111-113.

Checker, M. 2017. Stop FEMA now: social media, activism and the sacrificed citizen. Geoforum 79: 124-133.

Clarke, R.V. and A. Rolf. 2013. Poaching, habitat loss and the decline of neotropical parrots: A comparative spatial analysis. Journal of Experimental Criminology 9(3): 333-353.

Collyns, D. 2016. Tackling the smuggling of exotic animals in Peru. Peru. Online: https://www.youtube.com/watch?v=etJiiq-75og. Accessed 20/6/2020.

Dammert, L. and K. Sarmiento. 2019. Corruption, organized crime, and regional governments in Peru. In Rotberg R.I. (ed). Corruption in Latin America. Switzerland: Springer. Pp. 179-204.

Daut, E.F., D.J. Brightsmith, A.P. Mendoza, L. Puhakka and M.J. Peterson. 2015. Illegal domestic bird trade and the role of export quotas in Peru. Journal for Nature Conservation 27: 44-53.

Daut, E.F., D.J. Brightsmith and M.J. Peterson. 2015. Role of non-governmental organizations in combating illegal wildlife-pet trade in Peru. Journal for Nature Conservation 24: 72-82. 
Demmer, U. and A. Hummel. 2017. Degrowth, anthropology, and activist research: the ontological politics of science. Journal of Political Ecology 24(1): 610-622.

EIA. 2012. The laundering machine - how fraud and corruption in Peru's concession system are destroying the future of its forests. London: Environmental investigation Agency.

EIA. 2015. Deforestation by definition. Washington DC: Environmental Investigation Agency.

Fielding, N. and H. Thomas. 2001. Qualitative interviewing: researching social life. London: Sage.

Figueroa, J. 2014. Tráfico de partes e individuos del oso andino tremarctos ornatus en el Perú. Revista de la Academia Colombiana de Ciencias Exactas, Físicas y Naturales 38(147): 177-190.

Fletcher, R. 2017. Gaming conservation: Nature 2.0 confronts nature-deficit disorder. Geoforum 79: 153-162.

Gastañaga, M., R. MacLeod, B. Hennessey, J.U. Nunez, E. Puse, A. Arrascue, J. Hoyos, W.M. Chambi, J. Vasquez and G. Engblom. 2011. A study of the parrot trade in Peru and the potential importance of internal trade for threatened species. Bird Conservation International 21(1): 76-85.

Goodchild, M.F. 2007. Citizens as sensors: the world of volunteered geography. GeoJournal 69(4): 211-221.

Hawkins, R. and J.J. Silver. 2017. From selfie to sealfie: Nature 2.0 and the digital cultural politics of an internationally contested resource. Geoforum 79: 114-123.

Heuser, C. 2018. New president, old problems: corruption and organised crime keep Peru in crisis. Giga Focus, Latin America. 14.

ICCWC. 2014. Analysis of law enforcement efforts to combat wildlife and forest crime in Peru. Wildlife and forest crime analitic toolkit. Lima: International Consortium on Combating Wildlife Crime.

Lavorgna, A. 2014. Wildlife trafficking in the internet age. Crime Science 3(1): 5.

Leberatto, A.C. 2016. Understanding the illegal trade of live wildlife species in Peru. Trends in Organized Crime 19(1): 42-66.

Lovink, G. 2011. Networks without a cause: a critique of social media. Cambridge: Polity.

Lunstrum, E. 2017. Feed them to the lions: conservation violence goes online. Geoforum 79: 134-143.

Maldonado, A.M. and M.R. Peck. 2014. Research and in situ conservation of owl monkeys enhances environmental law enforcement at the Colombian-Peruvian border. American Journal of Primatology 76(7): 658-669.

McCubbin, S.G. 2020. The cecil moment: Celebrity environmentalism, nature 2.0, and the cultural politics of lion trophy hunting. Geoforum 108: 194-203.

McNeely, J.A., K.R. Miller, W.V. Reid, R.A. Mittermeier and T.B. Werner. 1990. Conserving the world's biodiversity. Gland, IUCN.

Mendoza, A.P. and N. Cavero. 2014. Comercio de animales silvestres en el mercado de Bellavista (Pucallpa, Ucayali) 2007-2012. Lima: Wildlife Conservation Society.

Morgan, J. and S. Chng. 2018. Rising internet-based trade in the critically endangered ploughshare tortoise astrochelys yniphora in Indonesia highlights need for improved enforcement of CITES. Oryx 52(4): 744-750.

Nelson, I.L. 2017. Interspecies care and aging in a gorilla 2.0 world. Geoforum 79: 144-152.

Newell, D.A., M.M. Pembroke and W.E. Boyd. 2012. Crowd sourcing for conservation: web 2.0 a powerful tool for biologists. Future Internet 4(2): 551-562.

Nijman, V. 2017. Orangutan trade, confiscations, and lack of prosecutions in Indonesia. American Journal of Primatology 79(11): 22652.

Ortiz, C. 2010. Aves silvestres comercializadas en el mercado de productores el Palomar-Arequipa. Boletin de Lima 159: 136-140.

Peh, K.S.-H. and O. Drori. 2010. Fighting corruption to save the environment: Cameroon's experience. Ambio 39(4): 336-339.

Quevans, N., N. Falcón and R. Elías. 2013. Fauna silvestre y productos derivados decomisados durante el período 2000-2007, Lima-Perú. Revista Salud y Tecnología Veterinaria 1(1): 14-18. 
Reuter, P. and D. O'Regan. 2017. Smuggling wildlife in the americas: scale, methods, and links to other organised crimes. Global Crime 18(2): 77-99.

Rocheleau, D.E. 2008. Political ecology in the key of policy: from chains of explanation to webs of relation. Geoforum 39(2): 716-727.

Shanee, N. 2012. Trends in local wildlife hunting, trade and control in the tropical Andes biodiversity hotspot, northeastern Peru. Endangered Species Research 19: 177-186.

Shanee, N. 2015. Informe sobre la necesidad urgente de cerrar el mercado de fauna silvestre de Bellavista, Pucallpa. Pucallpa: Neotropical Primate Conservation.

Shanee, N. 2016. Government and community based primate conservation initiatives in Peru. In M.T. Waller (ed.). Ethnoprimatology: primate conservation in the 21st century. Switzerland: Springer.

Shanee, N., A.P. Mendoza and S. Shanee. 2017. Diagnostic overview of the illegal trade in primates and law enforcement in Peru. American Journal of Primatology 79(11): e22516.

Speed, S. 2006. At the crossroads of human rights and anthropology: Toward a critically engaged activist research. American Anthropologist 108(1): 66-76.

Stonich, S. 1993. I am destroying the land! The political ecology of poverty and environmental destruction in Honduras. Boulder: Westview Press.

Sundström, A. 2015. Covenants with broken swords: corruption and law enforcement in governance of the commons. Global Environmental Change 31: 253-262.

TRAFFIC. 2019. Illegal wildlife trade. [accessed May 8 2019]. http://www.traffic.org/trade/.

van Uhm, D.P. and W.D. Moreto 2017. Corruption within the illegal wildlife trade: a symbiotic and antithetical enterprise. The British Journal of Criminology 58(4): 864-885.

van Vliet, N., J. Moreno, J. Gomez, L. L'haridon, L.N. de Aquino, F. Sandrin, L. Vanegas and R. Nasi. 2018. Current levels, recent historical trends, and drivers of wildmeat trade in the Amazon tri-frontier region between Colombia, Peru, and Brazil. In Nóbrega Alves, R.R. and U.P. Albuquerque (eds.). Ethnozoology. London: Academic Press.

Wall, T. and B. McClanahan. 2015. Weaponising conservation in the 'heart of darkness': the war on poachers and the neocolonial hunt. In Brisman, A., N. South and R. White (eds.). Environmental crime and social conflict: contemporary and emerging issues. London: Routledge.

Welch, S.E. 2017. Promised land or fool's paradise? A comparison of international wildlife crime and United States drug crime. International Immersion Program Papers 69. University of Chicago.

West, W. 2017. Unreported world: 'Peru's monkey business', Channel 4. Online: https://www.youtube.com/watch?v=1ks3i49M6BY. Accessed: 20/6/2020.

White, R. 2012. NGO engagement in environmental law enforcement: critical reflections. Australasian Policing 4(1): 7-11.

Whitehead, L. 2000. High-level political corruption in Latin America: a transitional phenomenon. In Tulchin, J.S. and R.H. Espach (eds.). Combating corruption in Latin America. Washington: Woodrow Wilson Center Press.

Wyatt, T. 2017. How corruption enables wildlife trafficking. In Williams, A. and P. Le Billon (eds.). Corruption, natural resources and development: from resource curse to political ecology. Cheltenham: Edward Elgar.

Wyatt, T. and A.N. Cao. 2015. Corruption and wildlife trafficking. U4 Issue 11: 1-39.

Wyatt, T., K. Johnson, L. Hunter, R. George and R. Gunter. 2018. Corruption and wildlife trafficking: three case studies involving Asia. Asian Journal of Criminology 13(1): 35-55. 